
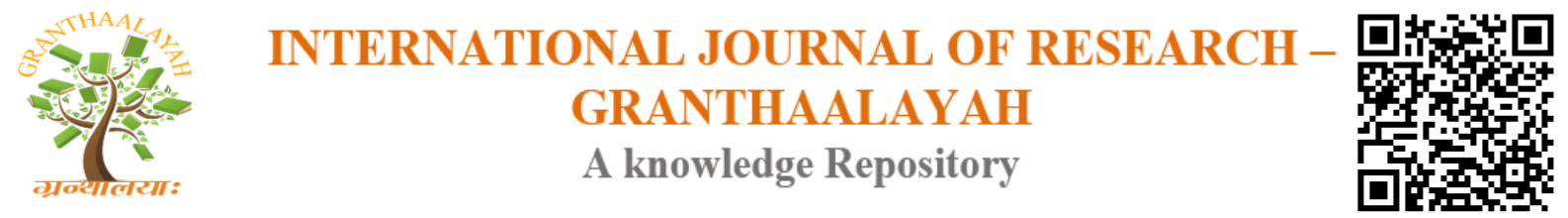

Management

\title{
SERVICE QUALITY OF PUBLIC SECTOR BANKS - A STUDY
}

\author{
Dr. G.Ramu ${ }^{* 1}$, V.Anbalagan ${ }^{2}$ \\ ${ }^{* 1}$ Research Advisor and Assistant Professor, P.G and Research Department of Commerce, Thiru. \\ Vi. Ka. Govt. Arts College, Tiruvarur, India \\ ${ }^{2}$ Assistant Professor, P.G and Research Department of Commerce, M.R. Government Arts \\ College, Mannargudi, India
}

\begin{abstract}
The banking scenario in India is of a highly developed nature, even though it is still far from achieving world standards in terms of size, products and services. Indian banks have realized that along with organic growth there is a need to grow inorganically as well, in order to be competitive with other players in the market. In this scenario, banking has been the focus of attention for the banking industry. Gronross, a service marketing expert, proposed that a service firm, in order to simultaneously attain success, must develop its service quality. Firstly, it must define how the consumers perceive service quality and secondly, determine in what way service quality is influenced. Consumers all over the world have become more quality conscious; hence there has been an increased customer demand for higher quality service. Service operations worldwide are affected by this new wave of quality awareness and emphasis. Therefore servicebased companies like the banks are compelled to provide excellent services to their customers in order to have sustainable competitive advantage, especially in the current trend. This study identifies quality dimensions significant to enable the banks to develop the strategies improving the quality of service delivery. It is found through the present study that the public sector banks in Karur district are losing market share to private and foreign banks. To survive in this competitive scenario all public sector banks are forced to introduce innovative services, schemes in order to retain existing customers and attract new customers.
\end{abstract}

Keywords: Service Quality; Private Sector Banks; Dimensions of Service Quality; Customer Satisfaction and Banking Services.

Cite This Article: Dr. G.Ramu, and V.Anbalagan. (2017). "SERVICE QUALITY OF PUBLIC SECTOR BANKS - A STUDY." International Journal of Research - Granthaalayah, 5(7), 639-645. https://doi.org/10.29121/granthaalayah.v5.i7.2017.2173.

\section{Introduction}

\section{Banking Services in India}

The banking scenario in India is of a highly developed nature, even though it is still far from achieving world standards in terms of size, products and services. Indian banks have realized that 
along with organic growth there is a need to grow inorganically as well, in order to be competitive with other players in the market. In this scenario, banking has been the focus of attention for the banking industry. The emergence of new economies and their rapid growth have been the most important contributing factors in the resurgence of banking. Changing lifestyles, rapid improvements in information technology and other service sectors, as well as increasing levels of income, have contributed to the growth of banking services in countries like India that are developing at a good pace. A decade ago, the banking sector was tough on a finger tip. But now it is possible. All the bank transactions with a connection to mobile handsets technology is the latest innovation means necessary to make. In addition, SMS Banking, Mobile Banking in India, and all the modernization are the major steps taken by banks towards Internet banking and ATMs. With all these tools and systems, banking has become a complete freedom to experience. Accounting, fund transfer and payment for centuries, has been followed in physical bank check which is now modernized. But the standing for hours in front of the cash counter and time to withdraw your own money is in foundation. The Indian banks are vying with one another to grab a pie of the banking service sector which has tremendous potential over the GDP in India. It also has its share of challenges in retaining customers, introduction of tech-savvy facilities and investments in such facilities, security concerns, Know Your Customer (KYC) norms, credit evaluation norms, etc.

\section{Concept of Service Quality}

Lewis and Booms (1983) had suggested that service quality results from a comparison of what customers expect from a service-provider with the provider's actual performance. According to them, "service quality is a measure of how well the service level delivered matches customer expectations. Delivering quality service means conforming to customers expectations on a consistent basis."

\section{Dimensions of Service Quality}

While evaluating service quality, consumers examine the following aspects: tangibility, reliability, responsiveness, assurance and empathy. Tangibility includes the service-provider's physical facilities, its equipment and appearance of the employees. Reliability is the ability of the firm to perform the service promised dependably and accurately. Responsiveness is the willingness of the firm's staff to help customer and to provide him with prompt service. Assurance refers to the knowledge and courtesy of the company's employees and their ability to inspire confidence in the customer. Empathy is caring and the individualized attention that the service firm provides to each customer.

\section{Managing Service Quality}

Gronross, a service marketing expert, proposed that a service firm, in order to simultaneously attain success, must develop its service quality. Firstly, it must define how the consumers perceive service quality and secondly, determine in what way service quality is influenced. He also suggested that the functional quality is an important dimension of perceived service than the technical quality. Therefore, the essence of effectiveness in managing services lies in improving the functional quality of a firm's service by managing the buyer-seller interaction as compared to traditional marketing activities. 


\section{Review of Literature}

The study of service quality of banking services and satisfaction level of bank customer has to start with a review of earlier works conducted and theories developed in this area to give a formal design to the present task. The reviews on the banking sector and the services involved with are elaborated along with the literature studies of service quality and customer satisfaction dimensions as follows:

Khan, Nisar Ahmed et al. (2005) conducted a study to examine the performance of scheduled commercial banks in general and public sector banks in particular during the post reform period. It also analyzed the performance of three categories of banks viz., public, private and foreign banks by comparing their capital adequacy, asset quality, profitability and participation in rural areas. It revealed that profitability and efficiency of these banks have improved considerably during the period, but the participation in rural areas in terms of number of offices, growth of credit, growth of deposits etc., have significantly declined during the reform period.

Krishnaveni, R. et al. (2005) analyzed the existing Indian banking scenario in the light of liberalization and globalization reforms in the country. They also studied the perceptions of the corporate customers regarding the service quality of their bankers. The study found that there is a wide gap between the strategies followed by the Indian banks when compared to the foreign banks. The situation is same in the case of customer perceptions of service quality.

Gopalakrishnan, $V(2004)$ has inquired the challenges of Indian financial services market. This study revealed that the entry of new foreign banks and private sector banks with their advanced knowledge base of automation in the banking operations and aggressive marketing strategies has pushed public sector banks to a tight corner. He wants the public sector banks, to survive and succeed by identifying their marketing areas, develop adequate resources, and convert these resources into healthy and efficient services and distribute them effectively satisfying the manifold tastes of customers.

Prabha, Divya et al. (2006), in their study analyzed the service quality perceptions of the corporate customers in Coimbatore regarding the services provided by their banks. For the study they considered both product and service based sectors and SERVQUAL scale based questionnaire for the survey. By this study it has been revealed that even though customers are more satisfied with the competence and customer orientation dimensions of service quality, still banks need to focus upon the aspects of communication, modernization and quickness of service.

Bhat, Mushtaq A. (2005) studied service quality perceptions of Indian banks in comparison with that of foreign banks. SERVQUAL instrument developed by Parasuraman et al. in the year 1988 and its five dimensions such as reliability, responsiveness, empathy, assurance and tangibility were used for collecting primary data. A major finding of the study was that Indian banks fall much below the perceptions of their customers on all dimensions of service quality. Foreign banks are exceeding the perceptions of their customers on tangibility and reliability dimensions of service quality. 
Krishna Chithanya, V. (2005) studied the meaning, nature and scope of financial activities in India and its features and to frame marketing strategy to attain service quality and to suggest effective channel of distribution. By this study, service quality is the difference between the perceptions of actual service quality and expectation of customers and the customer courtesy, credibility and security. It proposed a two way channel for distributing financial services such as, remote - T.V, Phone, PC etc., and face- to-face traveling, visiting offices etc.

Bauer, Hans H. et al. (2005) empirically examined characteristics of a website that transform into an extensive e-banking portals and to analyze different facets of the quality of services delivered through e-banking portals in order to process a service quality measurement model. The measurement model constructed in this study was based on different dimensions such as security and trust, basic service quality, cross-buying service quality, added value, transaction support and responsiveness. Here, the identified dimensions were classified on the basis of its nature as core services, additional services and problem solving services.

\section{Need for Service Quality in Banks}

The competitive climate in the Indian financial market has changed dramatically over the last few years. Business houses have entered into financial service activities. Public sector banks have started mutual fund trusts and other financial service subsidiaries. These subsidiaries have introduced new products in the market, which have competitive edge over products of the other banks. Even private sector and foreign banks have introduced innovative services. Almost all Indian banks have started experimenting with new services by offering the Automatic Teller Machine (ATM) that provides 24 hours services. The expectations of the customers have also changed nowadays. Many consumers expect a variety of services from the banks. Many household consumers, now, prefer to take consumer durable loans or buy an instant credit rather than save for a few years to buy the intended consumer durable.

\section{Scope of the Study}

Consumers all over the world have become more quality conscious; hence there has been an increased customer demand for higher quality service. Service operations worldwide are affected by this new wave of quality awareness and emphasis. Therefore service-based companies like the banks are compelled to provide excellent services to their customers in order to have sustainable competitive advantage, especially in the current trend. Customer satisfaction and retention has become a matter of concern in the banking industry and service quality has been identified empirically as the driver of them. But, there are discrepancies between what the banks think is quality service and what the customers expect from the banks.

\section{Importance of the Study}

This study identifies quality dimensions significant to enable the banks to develop the strategies improving the quality of service delivery. This will enhance the Bank's competitive position in the banking industry and ensure survival of the bank, especially in this era of keen competition. By measuring the satisfaction level of customers, financial institutions can develop customercentric service approach to deal with customers in order to avoid the tendency of existing 
customers switching to a competing bank. By identifying what customers expect and experience what the quality is. Banks can revise, redesign or repackage its service operations and tailor them to meet the expectations of the customers.

\section{Statement of the Problem}

The statement of problem enumerates the aspect of the current situation that the study is performed for. It insists the need to verify a theory or a need to address problems and challenges of policies and decision making in practice. After liberalization, privatization and globalization, the Indian public sector banking is facing stiff competition from Indian private sector and foreign banks. Private Banks and Foreign banks have been offering numerous innovative services in order to attract customers from public sector banks.

\section{Objectives of the Study}

Following are the objectives of the present study:

1) To examine the profile of the customers utilizing the services rendered by banks.

2) To measure level of expectation of the customers towards the banking services.

3) To analyze the service quality dimensions to determine the quality of the services provided by the banks.

4) To evaluate the level of satisfaction of the customers towards the banking services

5) To render suitable suggestions to refine the quality of banking services provided by the banks.

\section{Dimensions of the Study}

The present study takes the following dimensions for its analysis.

- Demographic factors of customers accessing banking services.

- Customer expectation

- Service quality of the Technical and Functional services provided by the banks.

- Satisfaction of the Customers.

- Customer retention.

- The dimensions were further split into various sub dimensions.

\section{Findings}

- The customers of the bank who are account holders are the respondents for this study and their satisfaction varies in different transactional services of the bank. The variation may be due to difference in quality or it can be in different cultural setting among service providers and customers as well.

- Service quality gaps in all dimensions including tangible, responsiveness, reliability, empathy, communication, assurance and accountability exist. The expectations of customers on factors measuring service tangibility yielded various average scores. Out of the items, customers are very much interested in the efficiency and effectiveness of the equipment used to deliver the services. 


\section{Suggestions}

Following are the suggestions for the development of the service quality of the public sector banks:

- Unnecessary formalities in providing loans and advances are the problems perceived in this study area. Though the formalities are universal in nature, steps may be taken to liberalize the procedures and formalities so that the people in this area may get the benefit of getting loans quickly with reasonable formalities.

- Most of the modernized services have not yet reached the branches of banks in this study area. The banks can take steps to modernize their branches with computers and internet to enable the customers to get quality services.

\section{Conclusion}

It is found through the present study that the public sector banks in Karur district are losing market share to private and foreign banks. To survive in this competitive scenario all public sector banks are forced to introduce innovative services, schemes in order to retain existing customers and attract new customers. At this junction, it is imperative to identify the services offered by public sector banking in Indian banking industry and to identify the determinants of customer's satisfaction towards public sector service quality.

\section{References}

[1] Bauer, Hans H. et al., (2005). Measuring the quality of e-banking portals, International Journal of Bank Marketing, Vol. 23, No.2, pp. 153-1 75.

[2] Benson (2006), Reforms in Banking sector and their impact in banking services, SAJOSPS, JulyDecember, pp 77-81.

[3] Bhat, Mushtaq A. (2005), Correlates of service quality in banks: An Empirical Investigation, Journal of Services Research, Vol. 5, No. 1, April-September, pp 77-99.

[4] Dhar, Upindar et al. (2004), Service with a difference A Comparative analysis of private and public sector banks, Prestige journal of Management and Research, Vo1.8, No. 12, AprilOctober, pp. 17-43.

[5] Golden, S. A. R. (2015). Regional Imbalance affecting quality of e-banking services with special reference to Tuticorin District-An Analysis. International Journal of Research, 2(3), 788-798.

[6] Golden, S. A. R., \& Franco, C. E. (2014). Role of Commercial Bank in the Growth of Micro and Small Enterprises. Golden Research Thoughts, 3 (7), 1, 5.

[7] Golden, S. A. R., (2015). Satisfaction of Customers towards User Friendly Technological Services offered by Public and Private Sector banks at Palayamkottai, Tirunelveli District. International Journal of Research, 2(3), 775-787.

[8] Gopalakrishnan, V. (2004), Marketing of Banking Services in the globalised scenario Emergency challenges, Indian Journal of Marketing, Vol. 34, No.5, May, pp. 26-28.

[9] Khan, Nisar Ahmed and Rahmatullah, Md. (2005), Performance of Commercial banks in India, Southern Economist, Vol. 44, No. 1, May 1, pp 55-58.

[10] Krishnaveni, R and Divyaprabha, D. (2005), The impact of globalization on banking industry, SAJOSPS, July-December, pp 74-80

[11] Lewis and Booms (1983), Service quality perceptions in banks: A comparative analysis, VISION - The Journal of Business Perspective, Vol. 9, No.1, January-March, pp 11 - 19. 
[12] Prabha, Divya and Krishnaveni (2006). Service quality perception of banking service - with reference to corporate customers, ACRM Journal of Business and Management Research, Vol. 1, No. 1, February, pp. 45-49.

[13] Sathye, Milind (2005), Privatization, Performance and efficiency: A Study of Indian banks, VIKALPA, Vol. 30, No. 1, January-March, pp 7-16.

[14] Velmurugan R.and Vanitha E., (2015) Service Quality of Public Sector Banks, PARIPEX Indian Journal Of Research, Volume: 4 , Issue : 4, April 2015, p.4. 